\title{
Influence of polypropylene microfibre (PPMF) dispersion procedure on fresh and hardened rendering mortar properties
}

\author{
Influência do procedimento de dispersão de microfibras \\ de polipropileno (PPMF) nas propriedades das argamassas \\ frescas e endurecidas
}

\begin{abstract}
Sérgio Roberto Andrade Dantas
Ramoel Serafini

Roberto Cesar de Oliveira Romano

Fúlvio Vittorino

Kai Loh

Abstract

his study was carried out to evaluate the influence of a polypropylene microfibre (PPMF) dispersion procedure on fresh and hardened state properties of rendering mortars. Specimens prepared with two different PPMF dispersion procedures were evaluated comparatively with reference specimens prepared without adding PPMF. Changes in the fresh properties were monitored using flow table, squeeze flow, and air-entrainment tests. The hardened state was characterized by capillary water absorption, airpermeability, dynamic elastic modulus (E), tensile strength according to the Brazilian test, and porosity by the Archimedes immersion method. Results show that the fresh mortar properties were not affected by dispersion procedure and all hardened mortar properties were statistically similar, except for the dimensional variation of the specimens. The study also shows that adding polypropylene microfibres in a dispersed form was more effective in terms of controlling total drying shrinkage than directly adding fibres to the cementitious matrix (as

${ }^{1,2}$ Sérgio Roberto Andrade Dantas ${ }^{1}$ Universidade de São Paulo São Paulo - SP - Brasil ${ }^{2}$ Instituto de Pesquisas Tecnológicas São Paulo - SP - Brasil

${ }^{3}$ Ramoel Serafini ${ }^{3}$ Universidade de São Paulo São Paulo - SP - Brasil

\section{${ }^{4}$ Roberto Cesar de Oliveira Romano \\ ${ }^{4}$ Universidade de São Paulo São Paulo - SP - Brasil}

${ }^{5}$ Fúlvio Vittorino 5 Instituto de Pesquisas Tecnológicas São Paulo - SP - Brasil

${ }^{6}$ Kai Loh 6Universidade de São Paulo São Paulo - SP - Brasil

Recebido em 01/03/19

recommended by the manufacturer) or the reference mortar.

Keywords: Polypropylene microfibre. Dispersion procedure. Drying shrinkage. Rendering mortars. Facade degradation process.

\section{Resumo}

O estudo avaliou a influência do procedimento de dispersão de microfibras de polipropileno (PPMF) nas propriedades de estado fresco e endurecido de argamassas de revestimento. Amostras preparadas com dois procedimentos diferentes de dispersão de PPMF foram avaliadas comparativamente com amostras de referência preparadas sem adição de PPMF. As propriedades frescas foram monitoradas utilizando flow table, squeeze flow e ar-incorporado. O estado endurecido foi caracterizado por absorção de água por capilaridade, permeabilidade ao ar, módulo elasticidade dinâmico (E), resistência à tração, de acordo com o teste brasileiro, e porosidade pelo método de imersão de Arquimedes. Os resultados mostram que as propriedades das argamassas em estado fresco não foram afetadas pelo procedimento de dispersão, enquanto no estado endurecido foram estatisticamente semelhantes, exceto a variação dimensional. A adição de microfibras de polipropileno de forma dispersa foi mais eficaz em termos de controle da retração total do que a adição direta de fibras à matriz cimentícia (conforme recomendado pelo fabricante) ou à argamassa de referência.

Palavras-chave: Microfibra de polipropileno. Procedimento de dispersão. Retração.
\end{abstract} Aceito em 07/08/19 Argamassa de revestimento. Processo de degradação de fachadas.

DANTAS, S. R. A.; SERAFINI, R.; ROMANO, R. C. de O.; VITTORINO, F.; LOH, K. Influence of polypropylene microfibre 7 (PPMF) dispersion procedure on fresh and hardened rendering mortar properties. Ambiente Construído, Porto Alegre, v. 20, n. 2, p. 7-23, abr./jun. 2020. 


\section{Introduction}

Facade finishing entails protective layers that enhance the durability and service life of a building. Therefore, their characteristics must be maintained over time to attend minimum performance levels required by regulations. It is well documented that fibres improve many properties of mortars, including tensile strength, flexural strength, thermal shock strength, toughness and can reduce drying shrinkage (ŞANAL; ÖZYURT; HOSSEINI, 2016; GESOGLU et al., 2016; YOUSEFIEH et al., 2017; AFROUGHSABET; BIOLZI; MONTEIRO, 2018; GUO; YANG; GAO, 2019). In this context, controlling properties such as modulus of elasticity, mechanical properties, permeability, water absorption, and retraction is extremely important to meet design requirements so that coatings last over time.

As soon as a mortar is applied on a facade, a continuous degradation process begins and will last during the entire service life of the element. The first manifestation is the presence of dirt spots and cracks, generally attributed to dimensional changes which, over time, may lead to overlapping deterioration mechanisms. Depending on the environmental characteristics, anomalies can occur due to loss of adhesion, leading to detachments because of the loss of cohesion (GASPAR; BRITO, 2010).

Rendering mortars are exposed to a permanent state of tension during their service-life since they have a large area over volume ratio and can be applied in different kinds of substrates under distinct environmental conditions. Therefore, factors of formulation (e.g. aggregates, pastes, thickness of the mortar layer), and external factors such as environmental conditions, mixing procedure, application, and curing conditions can affect the development of hardened state properties and performance in conditions of use (BASTOS, 2001 ${ }^{1}$ apud SILVA; CAMPITELI, 2008).

Among these factors, porosity can be highlighted. This property has a significant influence on the hardened properties and is intrinsically linked to composition, application procedures, and curing processes. According to Toledo Filho et al. (2005² apud ALY; SANJAYAN; COLLINS, 2008), the higher drying shrinkage observed in matrix incorporating fibres was attributed to the increase in porosity. Scrivener et al. (1996 ${ }^{3}$ apud ALY; SANJAYAN; COLLINS, 2008) reported that the tendency for pores to be connected is much higher in the vicinity of aggregate particles and this may be a similar case for PP fibres. This helps explain the higher sorptivity and the greater water loss during drying shrinkage of concretes with PP fiber.

Developing industrialized mortar coatings with air-entraining additives and water retainers based on cellulose molecules is common. Air-entraining admixtures are useful in plasticizing mixes to improve the workability of mortar and reduce the amount of mixing water. However, this addition induces the introduction of air bubbles which, despite making the application easier can affect some properties of the coating, mainly due to the increase in the porosity. Besides, a reduction in modulus of elasticity and compressive strength may also occur after the hardening process (ROMANO; TORRES; PILEGGI, 2015; SILVA et al., 2009).

The quality and durability of mortar coating are directly linked to its capacity to absorb deformations, measured by the modulus of elasticity (SILVA; CAMPITELI, 2008). The reduction of the modulus of elasticity is a beneficial factor, both for laying and wall covering. Thus, the smaller the modulus, the higher the deformation capacity of the mortar, reducing the possibility of cracking in the hardened state. Moreover, permeability is a relevant property due to its relationship with the access of aggressive agents to the substrate (QUARCIONI et al., 2011).

The mortars also present drying shrinkage over time, usually at the first ages. Shrinkage can be defined as the deformation of cementitious materials of any external mechanical solicitation in a constant thermodynamic environment. Therefore, drying shrinkage represents the numerical value of mortar deformation due to the water exchange with the external environment (ITIM; EZZIANE; KADRI, 2011).

Drying shrinkage usually depends on the volume of paste and the aggregates present in the mixture. The shrinkage intensity can also be affected by other factors as the continuity of its capillary network and density. It can be defined as the reduction in the volume of the unloaded and unrestrained element at a constant temperature, and the leading cause of such deformation is the loss of water during the drying process (ITIM;

1BASTOS, P. K. X. Retração e desenvolvimento de propriedades mecânicas de argamassas mistas de revestimento. São Paulo, 2001. 172 f. Tese (Doutorado em Engenharia da Construção Civil e Urbana) - Programa de Pós-Graduação em Engenharia Civil, Escola Politécnica, Universidade de São Paulo, São Paulo, 2001.

${ }_{2}$ TOLEDO FILHO, R. D. et al. Free, restrained and drying shrinkage of cement mortar composites reinforced with vegetable fibres. Cemento and Concrete Composites, v. 27, p. 537-546, 2005.

3SCRIVENER, K. L.; NEMATI, K.; M. Percolation of pore space in the cement past/ aggregate interfacial zone of concrete. Cemento and Concrete Research, v. 26, n. 1, p. 35-40, 1996. 
EZZIANE; KADRI, 2011; GÜNEYISI; GESOG; ÖZBAY, 2010; VALCUENDE et al., 2012; CARLSWÄRD, 2006).

Results presented in Altoubat and Lange (2001) showed a slight increase in shrinkage when fibrillated polypropylene fibres were added to the cement compositions, but according to Bouziadi, Boulekbache and Hamrat (2016) the use of fibres as a reinforcing mechanism can mitigate the stresses developed upon drying. Shrinkage decreases with increasing fibre dosage in mortar compositions, in which the following organic fibres are the most used: polypropylene; polymer; nylon; palm; and straw (NILI; AFROUGHSABET, 2010), increasing the hardness and flexibility, reducing shrinkage and resisting to micro-cracks.

This study was done to show the influence of the polypropylene microfibre dispersion procedure on the properties of rendering mortars in a fresh and hardened state.

\section{Experimental programme}

\section{Materials}

The reference mortar composition used in this work was formulated using white Portland cement (EUROPEAN..., 2000), dolomites \#20, \#40 and \#80, an air-entraining agent and water retention agents based on cellulosic ether molecules. White Portland cement was used to produce higher reflective surfaces, to be later evaluated by measurements of reflectance to solar radiation and colorimetry, where the use of grey Portland cement could significantly influence the measurements obtained due to their coloration.

The amount of water and aggregates were kept constant in all the mixtures. Polypropylene microfibers were used. The fibre content was added, considering the total volume of material used in the mortar composition $(0.14 \%-v o l$.) according to that indicated by the manufacturer to use in-situ work. The physical characteristics of Polypropylene microfibres are shown in Table 1.

The comparisons were performed using three sets of specimens and are described in Table 2. The materials used were selected based on the assumption of maintaining the same matrix previously evaluated, as shown in Table 3.

\section{Methods}

\section{Characteristics of raw materials}

The specific surface area (SSA) of materials was measured using the BET method. $\mathrm{N}_{2}$ gas/vapor adsorption was used on a Belsorp Max instrument with a pretreatment of the specimens at a temperature of $60^{\circ} \mathrm{C}$ and a pressure of $7 \times 10^{-5} \mathrm{MPa}$ for $24 \mathrm{~h}$ in a Belprep II - vac instrument. The real density analysis was determined using the Helium pycnometry method in a Quantachrome MVP 5DC multipycnometer. The particle size distribution of the finer particles was determined using laser granulometry in a Malvern Mastersizer LongBed with a detection range of $0.1-355 \mu \mathrm{m}$ and the dolomite particle size and shape characterization was characterized using a Dynamic Image Analyser (QicPic - Sympatec) with a detection range of 1-4000 $\mu \mathrm{m}$.

Table 1 - Polypropylene microfibre specification

\begin{tabular}{l|c|c|c|c}
\hline \multicolumn{1}{c|}{ Item } & Physical properties & Properties & $\begin{array}{c}\text { Referenc } \\
\text { e }\end{array}$ & $\begin{array}{c}\text { Permissible } \\
\text { range }\end{array}$ \\
\hline Material & $100 \% \mathrm{PP}$ & Length (mm) & 6 & 5 to 6 \\
Type & Monofilament & Diameter (micron) & 12 & 9 to 13 \\
Colour & Natural & Diameter (dtex) & 1.1 & $\leq 1.2$ \\
Fusion point & $160^{\circ} \mathrm{C}$ & Frequency of fibers (fibers/kg) & - & 1.62 billion \\
Ignition point & $365^{\circ} \mathrm{C}$ & Tenacity (cN/dTex) & 10 & $\geq 9.5$ \\
Modulus of elasticity & $9 \mathrm{Gpa}$ & Elongation (\%) & 22 & $\leq 25$ \\
Tenacity & $865 \mathrm{Mpa} / 9.5 \mathrm{cN} / \mathrm{dtex}$ & Product Moisture (\%) & 1.8 & $\leq 2$ \\
Density & 0.91 & Degree of dispersion & Level 2 & 2 to 3 \\
\hline
\end{tabular}


Table 2 - Description of the specimens

\begin{tabular}{c|c|l|l}
\hline Mixtures & Description & \multicolumn{1}{c|}{ Specimens } & Quant \\
\hline AR & Reference mortar (without PPMF) & cylindrical / prismatic & $05 / 03$ \\
AR+FPA & Mortar with addition PPMF in a grouped form & cylindrical / prismatic & $05 / 03$ \\
AR+FPD & Mortar with addition dispersed PPMF & cylindrical / prismatic & $05 / 03$ \\
\hline
\end{tabular}

Table 3 - Consumption, in $\mathbf{k g} / \mathbf{m}^{\mathbf{3}}$, of each raw material

\begin{tabular}{l|r}
\hline White Portland cement & 333.15 \\
\hline Dolomite \# 20 & 185.08 \\
Dolomite \# 40 & 1054.96 \\
Dolomite \# 80 & 277.62 \\
Water retainer & 1.94 \\
Air-entrainment & 0.16 \\
Water & 363.81 \\
Polypropylene microfibers & 1.33 \\
\hline
\end{tabular}

Table 4 shows the specific surface area and parameters related to the particle diameter for raw materials, while Figure 1 illustrates the particle size distribution.

Based on the proportions among the raw materials, shown in Table 2, the resulting granulometric curve in the compositions is presented in Figure 2. It was also chosen to give the cumulative curve, in which the results of characteristic particle diameters are also shown. As observed in Figure 2, the standard composition shows particle size continuity, with $90 \%$ of the particles smaller than $850 \mu \mathrm{m}$.

Figure 3 shows the quantitative mineralogical composition of white Portland cement, obtained by X-ray diffraction using the Rietveld method of analysis by powder diffraction, according to C1365-06 (AMERICAN..., 2011). Equipment used: Rigaku model Windmax 1000, operating on copper K $\alpha$ rad radiation with $40 \mathrm{kV}-20 \mathrm{~mA}$ and $2 \%$ min sweep ${ }^{4}$. Table 5 shows the chemical composition determined according to ABNT (ABNT, 2012a, 2012b, 2012c, 1997, 2013, 2012d, 2012e) and ASTM (AMERICAN..., 2015) standard.

\section{Mixing process}

The mixing procedure of the raw materials used to prepare the specimens is detailed below and presents only small differences.

Reference mortar - AR (without PPMF): all the water was put into the bowl of the Hobart N50 mixer, then all the dry powder was added for 1 minute with the equipment turned off. A time of 30s was given for particle wetting, followed by water and dry powder mixing for 90 seconds [30s speed 1 (low), 30s speed 2 (high) and 30s speed 1(low)].

AR+FPA (sample with grouped PPMF): the microfibres and dry powder were homogenized in a plastic bag for 30s before adding them to the bowl. The following steps were the same described for the reference specimen.

AR+FPD (sample with dispersed PPMF): microfibres were added to the bowl and dispersed with water for 90s using these speeds: 30s speed 1 (low), 30s speed 2 (high) and 30s speed 1 (low). Next, all the dry powder was added for 1 minute with the equipment turned off. The remaining process was the same described for the reference specimen.

${ }^{4}$ Compound identification was performed using Panalytical X-pert HighScore Plus software (version 4.5 (4.5. 0.22741) and diffraction patterns and structures provided by the free Crystallography Open Database (COD) database in 2016) and, eventually, diffraction patterns and ICDD (International Center for Diffraction Data) and ICSD (International Center for Structure Data) structures, respectively. 
Table 4 - Raw materials characteristic

\begin{tabular}{l|c|c|c|c}
\hline \multirow{2}{*}{ Materials } & \multicolumn{3}{|c|}{ Particle size $(\boldsymbol{\mu m})$} & Specific surface area \\
\cline { 2 - 5 } & $\mathbf{d - 1 0}$ & $\mathbf{d - 5 0}$ & $\mathbf{d - 9 0}$ & $\mathbf{( \mathbf { m } ^ { 2 } / \mathbf { g } )}$ \\
\hline White Portland cement & 2.6 & 17.7 & 19.5 & 0.86 \\
Dolomite \#20 & 975.1 & 1242.1 & 1620.5 & 0.16 \\
Dolomite \#40 & 24.3 & 230.0 & 739.6 & 0.56 \\
Dolomite \#80 & 4.5 & 38.3 & 133.9 & 0.80 \\
\hline
\end{tabular}

Figure 1 - Particle size distributions of materials

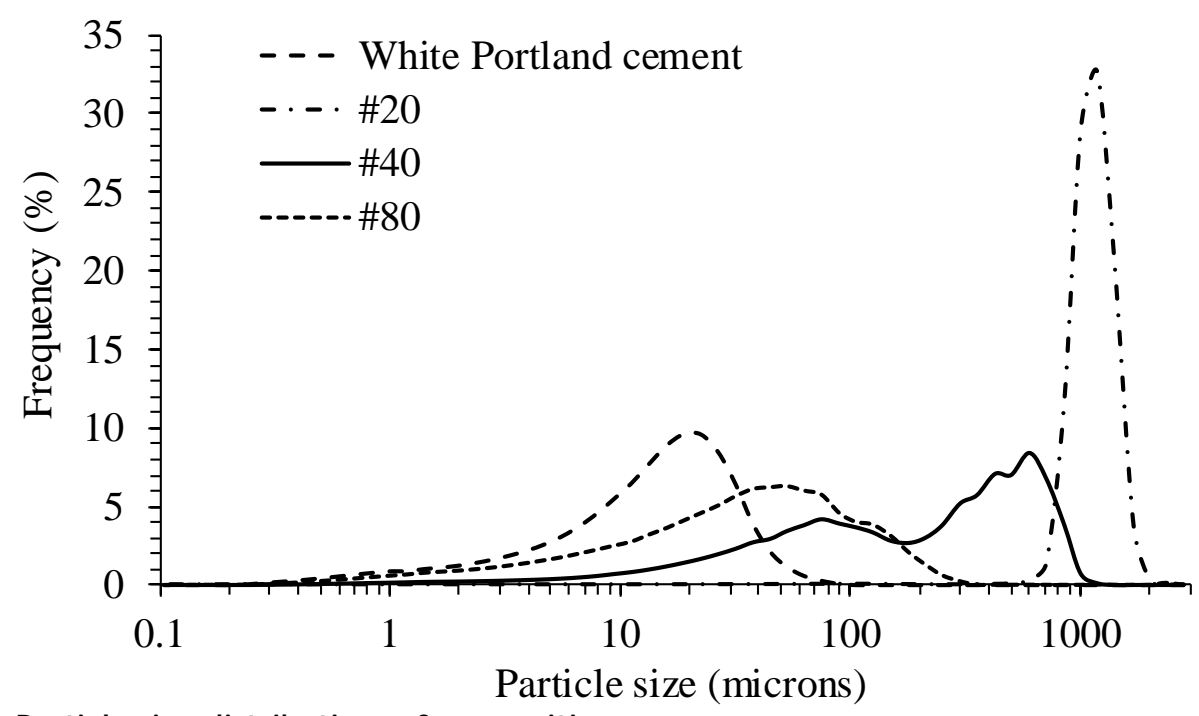

Figure 2 - Particle size distributions of compositions

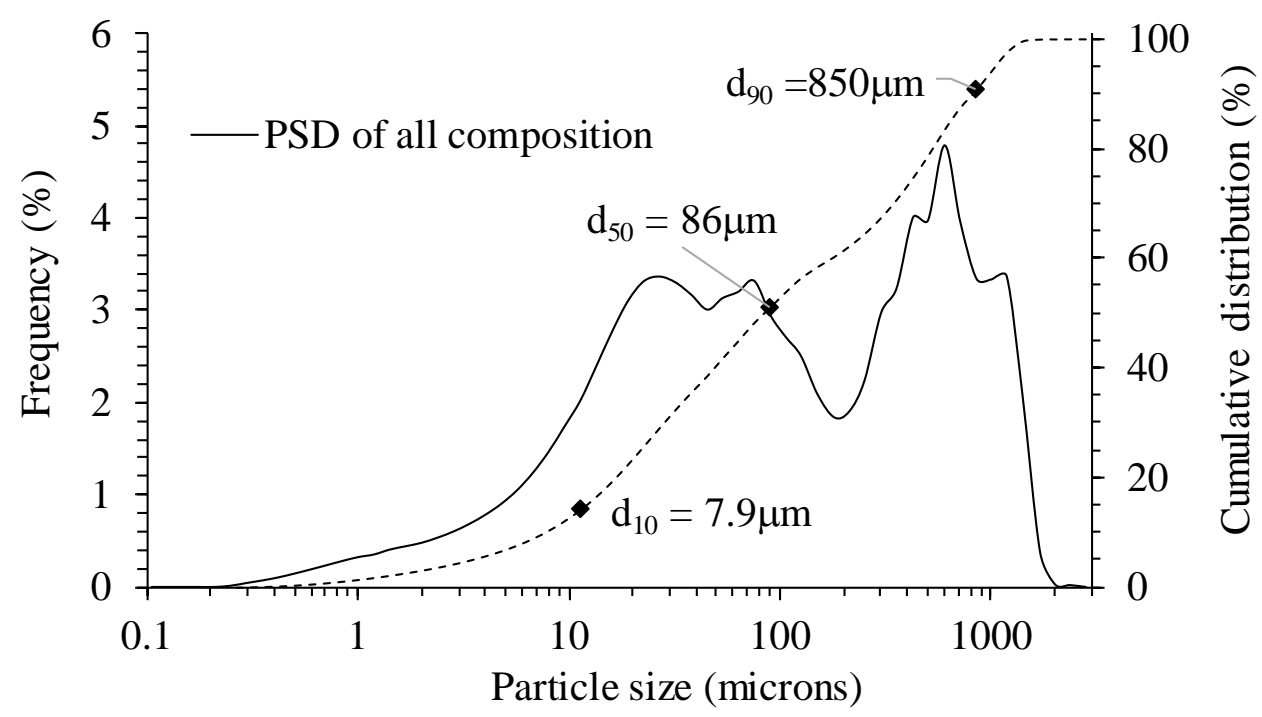

Influência do procedimento de dispersão de microfibras de polipropileno (PPMF) nas propriedades das argamassas 11 frescas e endurecidas 
Figure 3 - X-ray Diffraction of White Portland Cement

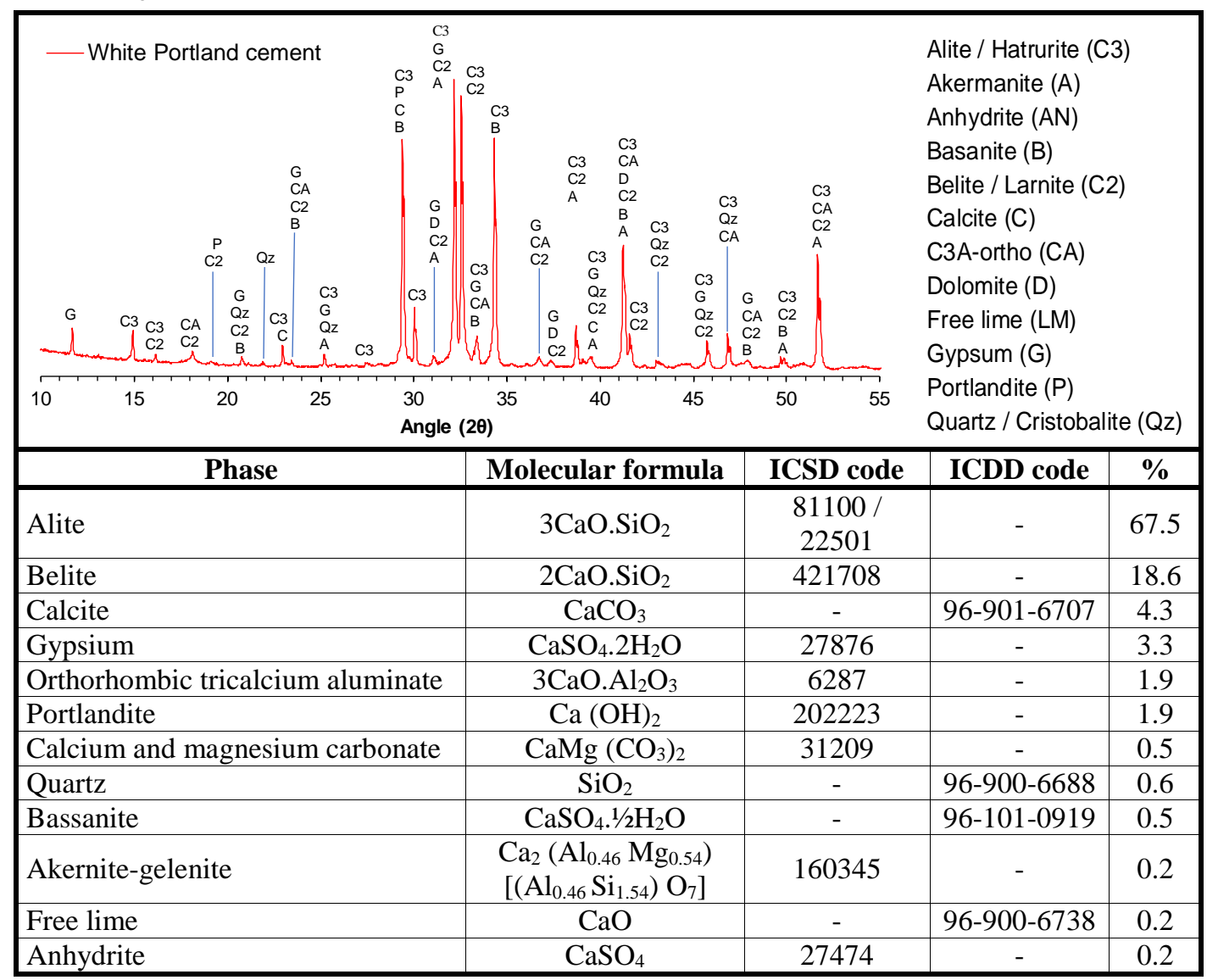

Table 5 - Chemical composition of cement

\begin{tabular}{l|c|c}
\hline \multicolumn{1}{c|}{ Compound } & White CEM I (\%) & Limited NBR-12989/93 (CPB) \\
\hline $\mathrm{LOI}$ & 2.48 & $\leq 27.0$ \\
$\mathrm{SiO}_{2}$ & 21.6 & --- \\
$\mathrm{Al}_{2} \mathrm{O}_{3}$ & 4.60 & --- \\
$\mathrm{FeO}_{3}$ & 0.33 & --- \\
$\mathrm{CaO}$ & 67.5 & --- \\
$\mathrm{MgO}$ & 0.59 & $\leq 10.0$ \\
$\mathrm{SO}_{3}$ & 2.83 & $\leq 4.0$ \\
$\mathrm{Na}_{2} \mathrm{O}$ & 0.13 & --- \\
$\mathrm{K}_{2} \mathrm{O}$ & 0.61 & -- \\
$\left.\mathrm{Alkaline} \mathrm{equivalent} \mathrm{(in} \mathrm{Na}_{2} \mathrm{O}\right)$ & 0.53 & --- \\
$\mathrm{CaO}$ & 2.26 & --- \\
$\mathrm{RI}$ & 0.43 & $\leq 7.0$ \\
$\mathrm{CO}_{2}$ & 0.67 & $\leq 25.0$ \\
\hline
\end{tabular}

Note: Alkaline equivalent (in $\mathrm{Na}_{2} \mathrm{O}$ ) $=\% \mathrm{Na}_{2} \mathrm{O}+0.658 \times \% \mathrm{~K}_{2} \mathrm{O}$ and LOI: Loss on ignition.

Homogenization of the fibre with the dry powders was done in a plastic bag for 30 seconds to separate the fibres before putting all the material into the mixing equipment. The fibres are commercialized in a tangled form, which makes it difficult to homogenise them while mixing the mortar. The pre-mixing in a plastic bag can even be done by the worker on site to obtain a better homogenization of the fibers.

\section{Fresh state properties}

The fresh state properties were evaluated using a flow table test (ABNT, 2016), squeeze flow test (ABNT, 2010), and air-incorporation using the gravimetric method (ABNT, 2005a). 
Flow table test: the test is performed by positioning the conical mould centrally on the table and filling it with three successive layers of mortars, with approximately equal heights. It is then tamped fifteen, ten and five times, respectively, with a tamping rod. The mortar should be levelled out by passing the metal ruler close to the edge of the conical mould with short back and forth movements, eliminating any particles around the frame with a clean, dry cloth. The conical mould is then removed vertically, and the crank is turned so that the table goes up and down 30 times in 30s smoothly. After the last turn, the spread is measured using a caliper. These measurements should be performed in terms of the diameter and they were taken in pairs of points uniformly distributed along the perimeter (ABNT, 2016).

Squeeze flow: tests were conducted on a universal testing machine (Instron 5569) with a $1 \mathrm{kN}$ load cell. Samples were prepared in a metallic plate with smooth surfaces to guarantee a non-absorption condition, and a cylindric mould (diameter of $101 \mathrm{~mm}$ and width of $20 \mathrm{~mm}$ ) was used. The tests were performed using a displacement rate of $0.1 \mathrm{~mm} / \mathrm{s}$ to a maximum displacement of $18 \mathrm{~mm}$ or maximum load of $1 \mathrm{kN}$, as shown in Figure 4.

Air-entrainment: tests were performed according to the gravimetric method, using a cup of 400 ml volume and determining the mass needed to fill it. The values of air entrainment were calculated based on the mortar's water content and the real density of the dry powder.

\section{Hardened state properties}

The moulded specimens were cured for 28 days under controlled temperature and humidity conditions (respectively, at $23^{\circ} \mathrm{C}$ and $50 \%$ ). The hardened properties were monitored by water absorption by capillarity (ABNT, 2005c), air-permeability, dynamic elasticity modulus (E) (ABNT, 2009) tensile strength by the Brazilian testing method (ABNT, 2011), porosity (Archimedes method) and drying shrinkage test (ABNT, 2005b). The results obtained were statistically evaluated using One-way ANOVA followed by the Tukey statistical test.

Porosity: measured according to the Archimedes water immersion test, based on the dry, wet, and immersed mass. The mass is determined on dried specimens and after immersion in water and under vacuum during 2.5 h. The total porosity was calculated according to Eq. (1), where $\rho_{\mathrm{REL}}$ is the relative density of mortar.

Total porosity $(\%)=\left(1-\rho_{\text {REL }}\right) \times 100 \%$

Eq. 1

Air-permeability: measured according to the vacuum-decay method (SELMO, 1986; SALVADOR, 2005; ROMANO, 2013). The apparatus used was a vacuum pump connected to a suction chamber that is in contact with the surface of the mortar. When the vacuum pump is turned on a transducer registers the pressure variations in function of time until the pressure stabilises. Samples were sealed using PVC plastic to guarantee the unidirectional flow. The test starts when the vacuum is turned off, and the time it takes for the applied vacuum pressure to extinguish is quantified. The permeability (expressed in $\mathrm{k}_{1}\left(\mathrm{~m}^{2}\right)$ values) is calculated using the Forchheimer equation Eq. (2), considering two basic hypotheses: negligible air-compressibility and using just the linear part of the equation.

$$
\frac{\Delta P}{L}=\frac{\mu}{k_{1}} v_{S}+\frac{\rho}{k_{2}} v_{S}^{2}
$$

$\mathrm{L}$ is the sample thickness, and $\mu$ and $\rho$ are, respectively, the fluid viscosity, and density, vs. is the speed of airpercolation and $\Delta \mathrm{P}$ is the pressure variation, for which vs. $\mu$, and $\rho$ are measured or calculated. The term $\rho v s / \mathrm{k}_{1}$ shows the viscous effect of fluid-solid interaction, while the term $\rho v s^{2} / \mathrm{k}_{2}$ represents the inertial effects. The terms $\mathrm{k}_{1}$ and $\mathrm{k}_{2}$ are thus known as Darcian and non-Darcian permeability constants. However, $\mathrm{k}_{2}$ was not used to compare the results in this work (INNOCENTINI, 2009).

\section{Figure 4 - Squeeze Flow test}

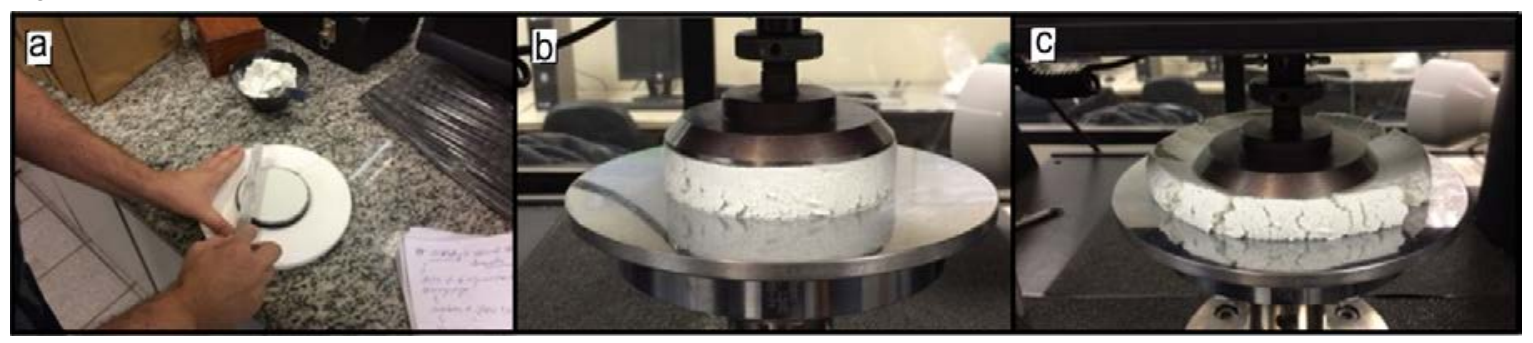

Influência do procedimento de dispersão de microfibras de polipropileno (PPMF) nas propriedades das argamassas 13 frescas e endurecidas 
Dynamic elasticity modulus (E): measured according to the Brazilian standard (ABNT, 2009) using PUNDIT (Portable Ultrasonic Non-destructive Digital Indicating Tester) equipment with frequency transducers of 200 $\mathrm{kHz}$ and a circular cross-section with a diameter of $20 \mathrm{~mm}$.

Tensile strength in diametrical compression: measured according to the Brazilian standard (ABNT, 2011) using Emic DL10000 equipment with continuously applied load at a speed of 400N/s until the rupture in test specimens.

Water absorption by capillarity: the specimen was partially sealed with beeswax at one of their ends at the height of $\pm 3 \mathrm{~cm}$, to avoid water absorption, thus forcing the water to penetrate only by the contact area. Afterwards, the specimens were placed on grids, inside a box with a $1 \mathrm{~cm}$ height of water. The water absorption of the samples was determined to weigh in the following intervals: 0h (dry mass), 15', 30', 1h, 2h, 4h, 8h, 24h, and 48h.

Dimensional variation (shrinkage): measured according to Brazilian standards (ABNT, 2005b), using 25 x 25 x $285(\mathrm{~mm})$ test specimens. The dimensional change of the samples was determined by a comparator clock with a resolution of $0.001 \mathrm{~mm}$ at intervals of 2 times a day, for 28 days.

\section{Statistical analysis}

To determine the influence of fibre dispersion, two statistical methods were used: one-way ANOVA and the Tukey test for comparative evaluation between pairs. These methods were used to indicate which dispersion method showed the lowest variation.

\section{Results and discussion Fresh state properties}

Table 6 shows the spreading of the mortars obtained by the flow-table test and the air-incorporation results.

The rendering mortars need to present spreading capacity to be considered adequate to be applied in a facade. Results indicate that all mortars show the same consistency and sufficient spreading capacity, demonstrating that the use or dispersion method of PPMF does not affect the mortar consistency. However, the addition of PPMF, even without a change in the dispersion procedure increased air-incorporation when compared to the reference mortar.

The squeeze flow method has been used to evaluate the rheological behaviour of pastes, plasters, extruded building materials, and different types of mortars as an alternative, complementary method. This method has been adopted to simulate processing and application conditions, for instance slipping, the material-shear element interfaces and measuring fibre-containing pastes. The test's geometry changes during gap reduction and creates flow conditions similar to those that involve processing and application of mortars, such as pumping and spraying, spreading and finishing and squeezing between bricks. This method was recently standardized in Brazil (ABNT, 2010) for rendering and masonry mortars.

The squeeze flow test does not simulate the most common problem which is the loss of contact between the material and sheer element, especially for materials with plastic characteristics such as mortars. This method is adequate to evaluate mixtures with any level of consistency and combinations with the addition of fibres. In the case of rendering mortars, the test simulates the processing conditions as spreading and finishing.

According to Afroughsabet, Biolzi and Monteiro (2018) and Sun and Xub (2009), an increase in the content of PP fibres results in a reduction in the workability. Thus, the choice for evaluating the fresh state by the squeeze flow method was based on the fact that the use of the fibre and its dispersion procedure could affect the workability of the mortars, which is difficult to identify only with the consistency table test. Thus, it was possible to more carefully monitor the impact of the dispersion procedure of the fibres on the workability of the coating. Figure 5 shows the results obtained in the mortars after 5 min of mixing.

Similar curves indicated that even with the imposition of a more severe shear condition, there was no impact on the workability. The qualitative perception of the consistency of the mortar, was also maintained, according to the mason who applied the material. This is a relevant factor since the mobility of the mix is of major importance in real scale applications. The result obtained showed the same consistency for the three mixtures studied (AR, AR+FPA, and AR+FPD) using the same fibre content ( $0.14 \%$ in volume) for the compositions. 
Table 6 - Entrained air and flow table test results

\begin{tabular}{c|c|c|c|c}
\hline Mixtures & $\begin{array}{c}\text { Spreading } \\
\text { (mm) }\end{array}$ & $\begin{array}{c}\text { Mortar mass } \\
\text { (g) mc }\end{array}$ & $\begin{array}{c}\text { Entrained air } \\
\text { (\%) }\end{array}$ & $\begin{array}{c}\text { Water added } \\
\text { (g) }\end{array}$ \\
\hline AR & 226.3 & $1,563.7$ & 24.0 & 425.0 \\
AR+FPA & 223.5 & $1,543.1$ & 26.2 & 425.0 \\
AR+FPD & 227.3 & $1,544.3$ & 26.1 & 425.0 \\
\hline
\end{tabular}

Note: $\mathrm{mc}=$ container mass + mortar mass

Figure 5 - Squeeze flow results

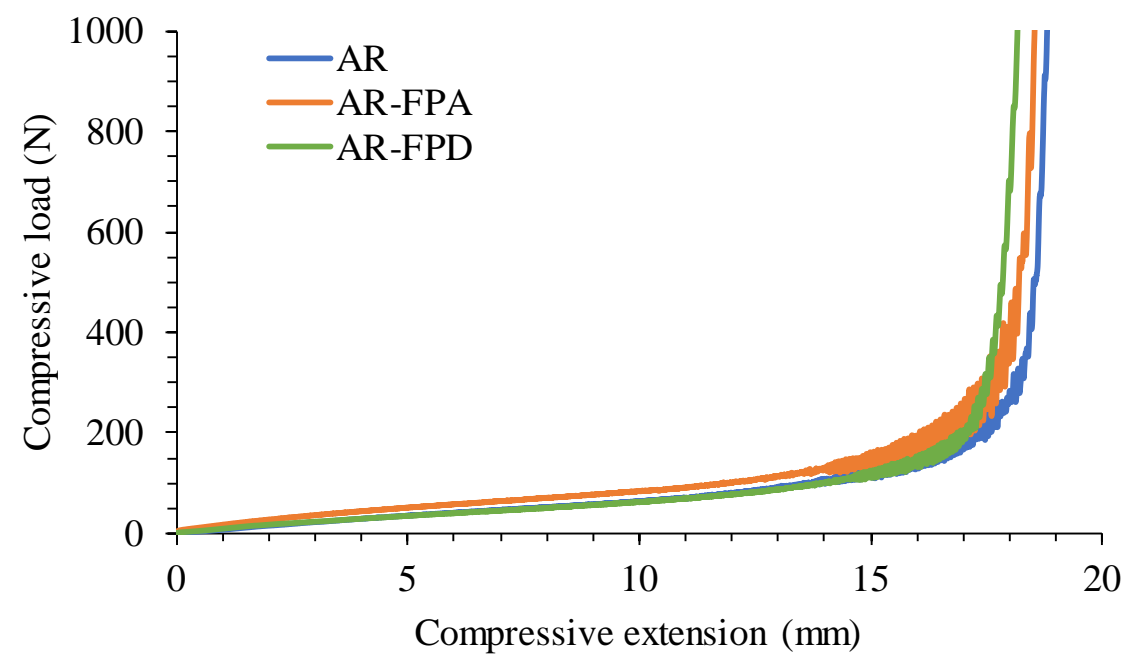

The three stages of the test were observed: in the first one, applying a small displacement, the material behaves as a solid exhibiting an elastic deformation, which is related to the material yield stress. By increasing the displacement, the elongation and radial shear can be observed, exceeding the forces that kept the material under elastic behaviour, indicating that the mortar is flowing. Large deformations without a significant increase in the compressive load can suggest that these mortars present adequate workability, so they are easy to apply. The squeeze flow test simulates the mortars which are used in different spreading conditions.

In the last stage of the test, there is a significant increase in the compressive load, even with low deformation of the material, because dolomite particles are in contact, increasing the frictional forces and a more significant interaction through interlacing of fibres, causing some restrictive effects to the flow. This third stage is characterized by the behaviour in which the application of this kind of material tends to be hampered due to the high loads involved.

\section{Hardened state properties}

The properties of PPMF were evaluated as a function of the dispersion procedure. Figure 6 summarizes the results of the hardened properties of each mortar, such as porosity, air-permeability, modulus of elasticity and tensile strength.

The total porosity and dynamic modulus elasticity of the mortars show a significant correlation $\left(\mathrm{R}^{2}=0.87\right)$. A decreasing trend line is observed, which means a higher total porosity results in a smaller modulus of elasticity. The smaller the modulus, the higher the deformation capacity of the mortar, thus reducing the possibility of cracking in the hardened state (SILVA et al., 2009). The reduction of the modulus of elasticity is paired with the decrease of the mechanical properties due to the increase in total porosity. According to Aly, Sanjayan and Collins (2008) the addition of PP fibres increases the nano-porosity and it provides a more refined micro-porestructure, which influences the drying shrinkage rate and results in high porosity in the vicinity of PP fibres due to the increase in mesopores in this zone.

The amount of water absorbed by a material is associated with the void content present in its microstructure, which, in turn, determines the porosity of the material (QUARCIONI et al., 2011). The use of polypropylene fibres significantly affects the microstructure of the mortar as it reduces the amount, size and orientation of 
$\mathrm{CH}$ crystals and generates micro voids. Another effect is that it reduces the voids and micro cracking at the interfacial transition zone between aggregate and cement paste (SUN; XUB, 2009).

The air-permeability and apparent porosity tests between mortars showed a very poor correlation $\left(R^{2}=0.22\right)$. The results show that the higher the apparent porosity, the greater the air-permeability of the mortars.

The tensile strength versus the total porosity of the system in the experimental test showed a moderate correlation $\left(\mathrm{R}^{2}=0.55\right)$. This correlation was expected; however, in this study, an observation could not be done since statistical evaluations proved that there are no differences between the mortars in the function of porosity or mechanical strength. Therefore, it cannot be related to the results of the shrinkage presented later.

However, according to Islam and Das Gupta (2016), the addition of polypropylene fibre provides adequate tensile strength to concrete in addition to controlling shrinkage cracks. Ramezanianpour et al. (2013) state that adding PP fibres to concrete reduces the compressive strength, but both splitting tensile and flexural strengths increase first and then decrease with a higher amount of fibre.

According to Ma, Tan and Wu (2002), when small quantities of polypropylene macrofibres are mixed into the cement matrix, the interlocking network characteristics of the fibres will prevent the large particles from sedimenting. The amount of bleed water may be reduced. On the other hand, because of the cohesion between the fibre and the cement matrix, the tensile strength of the fresh concrete will increase. If the tensile strength of the fresh concrete is larger than the tensile stress, the plastic shrinkage cracking will decrease or will even be eliminated.

According to Afroughsabet, Biolzi and Monteiro (2018), the presence of fibres has a considerable influence on the mechanical properties of concrete. The reduction in mechanical properties may be a matter of concern regarding laying for structural masonry, or even regular masonry. However, it does not tend to be of great importance for rendering mortars, except for adherence and integrity purposes. Among the three mixtures evaluated, mortar AR+FPD presented the lowest values of the elastic modulus due to the higher porosity.

\section{Figure 6 - Summary of hardened mortar properties}

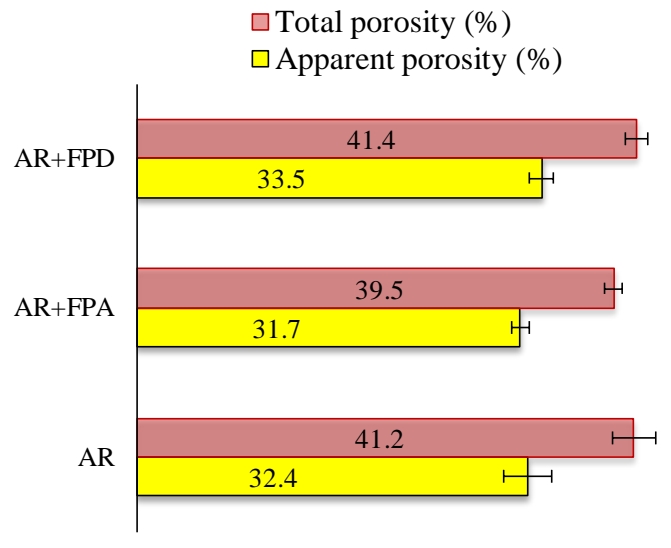

Tensile strength in diametral compression

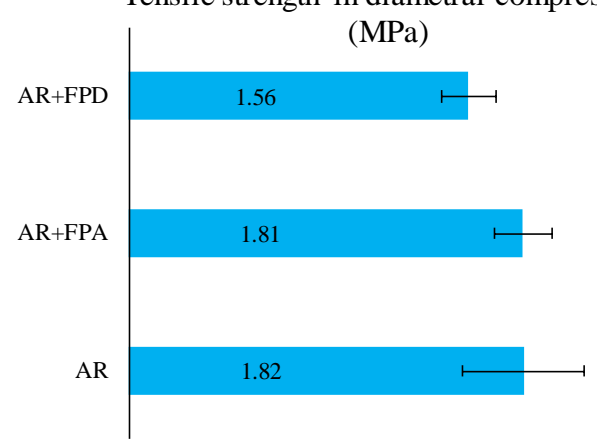

Air permeability (x10-11 m²)

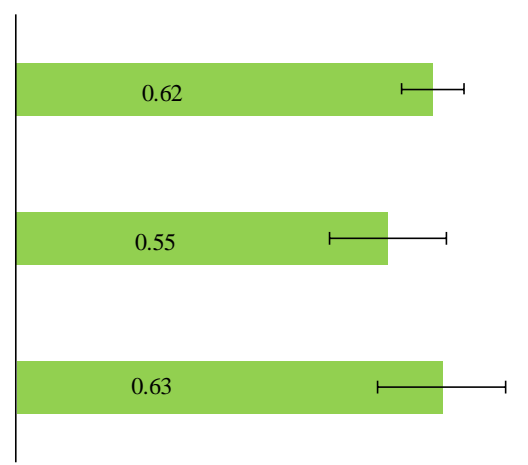

Dynamic modulus of elasticity (GPa)

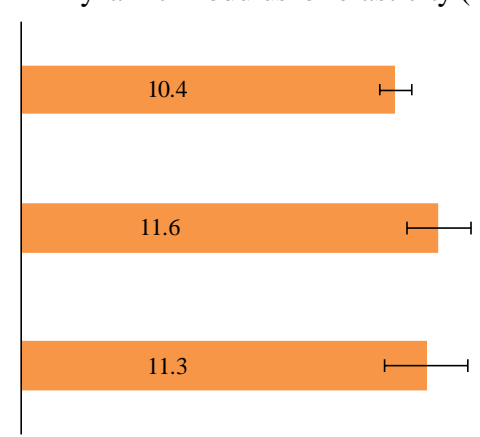


Figure 7 - Correlations of hardened mortar properties
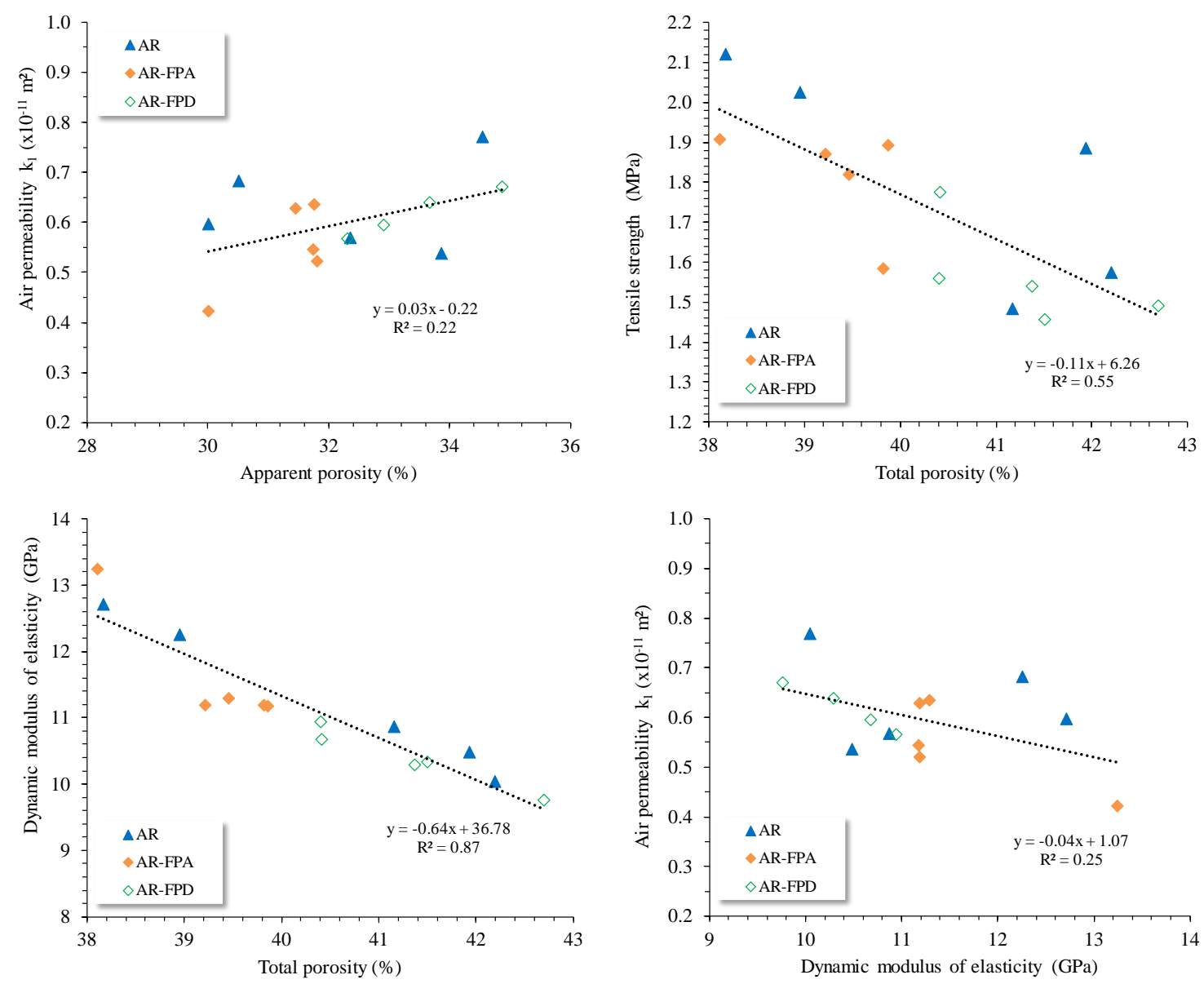

According to Aly, Sanjayan and Collins (2008), PP fibres contribute to the increase in elastic modulus of cementitious materials. The results showed that the higher the content of admixed PP fibres, the lower the cracking resistance of the mixture. However, the evaluation of the dynamic modulus of elasticity versus air permeability shows very poor correlation $\left(\mathrm{R}^{2}=0.25\right)$. In general, it can be observed that all the mixtures presented similar dynamic modulus of elasticity values, as well as values of air permeability, not allowing the selection of a better option. However, the mortar AR+FPD appears to be the only one that presents a more linear behaviour when compared to its peers and with smaller variance when compared to the others.

Although no statistically significant difference was observed in any of the cases, and the porosity variation was small, the correlation between the porosity and the other properties in the hardened state is of great importance. The statistical analysis was conducted between sample groups, and the similarity between them was confirmed. In the same specimen, the porosity was measured, the other properties were evaluated as well, which makes the correlation between them relevant. Figure 7 shows the correlation properties in the hardened state.

\section{Permeability of the mortars}

Polypropylene fibres have hydrophobic levels, which protect them against wetting with cement paste. The hydrophobic nature of polypropylene does not affect the amount of water needed for cementitious materials; therefore the presence of polypropylene fibres can cause a delay in starting the degradation process by reducing permeability and the amount of shrinkage (KAKOOEI et al., 2012).

For water absorption tests on rendering mortars, all mixtures reached saturation after 48 hours of immersion. The addition of air-entraining admixtures in the studied mortars shows a larger internal volume of air for the reference mortar (AR) and a slight reduction of the capillarity coefficient when compared to the other two mortars AR+FPA and AR+FPD. The higher formation of microscopic air bubbles in the AR mixtures leads to 
the interruption of the capillaries and consequently prevents the absorption of water inside the mortars (SILVA et al., 2009; QUARCIONI et al., 2009).

According to Saiz-Martínez et al. (2018), in terms of water absorption by capillarity, a higher absorption coefficient was obtained in recycled mortars due to higher air content. In the case of fibre addition, a slight decrease in this coefficient is not significant; that is why it cannot be concluded that including fibres leads to a better behaviour of the material in this respect.

According to Islam and Das Gupta (2016), with the addition of polypropylene fibre, both water and gas permeability coefficients were increased. Thus, the water and gas permeability increase in coefficients might suggest restricting the use of polypropylene fibre content in the case of structural elements exposed to water (such as water tanks, dams, spillways, swimming pools) and harmful gases.

The permeability of mortars at the age of 28 days was evaluated using the capillary coefficient obtained through water absorption as a function of time. The average results of the capillary coefficient for each mortar are shown in Figure 8.

\section{Drying shrinkage}

The behavioural prediction forms of mortars are very complex to be identified since such a phenomenon is an interaction of several physical mechanisms influenced by many parameters (MEHTA; MONTEIRO, 2008) and is intimately related to the change in relative humidity $(\mathrm{RH})$ due to the evaporation of free water from the capillary pores in the cement paste (CARLSWÄRD, 2006).

The addition of any type and fibre content results in a reduction in the drying shrinkage and a higher reduction in the shrinkage strain can be attained as a result of increasing the fibre volume fraction (AFROUGHSABET; BIOLZI; MONTEIRO, 2018). However, while polypropylene fibres, in general, are effective in controlling plastic shrinkage cracking in cementitious materials, a finer fibre is more effective than a coarser one, and a longer fibre is more effective than a shorter one. Further, fibre fibrillations appear to be highly effective in controlling plastic shrinkage cracking (BANTHIA; GUPTA, 2006).

Polypropylene fibre can improve the toughness of the mortar, effectively inhibiting the drying shrinkage, and also enhancing the anti-cracking properties. The added amount of PP fibre in aeolian sand mortar is appropriate to be $1.3 \mathrm{~kg} / \mathrm{m}^{3}$ (GUO; YANG; GAO, 2019). Besides, the experimental results have shown that the addition of short polypropylene fibres to the mortar mixture was more efficient at restraining crack formation due to plastic shrinkage (PELISSER et al., 2010).

Figure 9 shows the evolution of the drying shrinkage as a function of time. Each point in the curve corresponds to the mean retraction values of three groups of specimens. The results show the same tendency in the drying shrinkage intensity at the beginning of the process. However, the drying shrinkage rate is much higher at the end of the 28 days for blends with microfibres added in a grouped form. On the other hand, the shrinkage decreases when the microfibres are added dispersedly to the blend.

Figure 8 - Water absorption by capillarity $\left(W\right.$ in $\left.\mathbf{k g} / \mathrm{m}^{2} \times \sqrt{h}\right)$

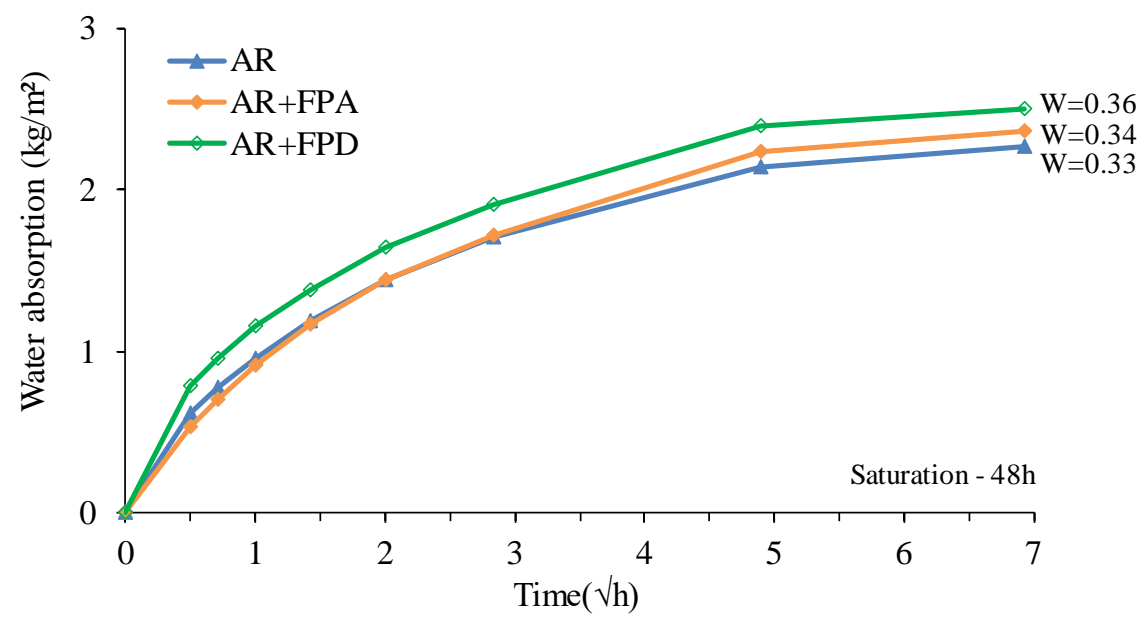


The AR+FPA composition presented the highest shrinkage values (75\%) among the samples tested. The final measured shrinkage of the mortars AR and AR+FPD were $66 \%$ and $50 \%$, respectively. The results indicate that with the better dispersion of the fibre, less shrinkage and less distribution of the results were quantified. The link that hinders the propagation of the micro-cracks has been achieved satisfactorily, converging with the results presented by Ma, Tan and Wu (2002), Nili and Afroughsabet (2010) and Guo, Yang and Gao (2019).

The polypropylene fibres cannot prevent the movement of cement paste at an early age and maintain the volume stability because of its low elastic modulus (BOUZIADI; BOULEKBACHE; HAMRA, 2016). However, adding fibres not only decreases cracking due to drying shrinkage, but also deferred the initial cracking time in a way that the first crack appears after $144 \mathrm{~h}$ according to Yousefieh et al. (2017).

The most important factor influencing the drying shrinkage is the amount and composition of cement paste, in addition to the structural geometry and drying conditions (CARLSWÄRD, 2006). In practice, this implies that the shrinkage for a given w/c-ratio can be reduced by minimizing the water amount and maximizing the content of coarse aggregates. According to Nmai et al. (1998 ${ }^{5}$ apud CARLSWÄRD, 2006), the effect of coarse aggregates on the shrinkage is two-fold. A high coarse aggregate content will reduce the water and paste demand of the mix at the same time provides restraint to the drying shrinkage of the paste. Hard and rigid aggregates such as dolomite, granites, feldspar, limestone, and quartz should be used to maximize the restraining action and produce concrete with low shrinkage.

Considering that the most critical factor influencing the drying shrinkage is the amount and composition of the cement paste, and that the mortars have the same structure (same content of fibres and coarse aggregate) and the same w/c ratio, it can be concluded that the control of retraction is directly associated with the mode of dispersion of the fibre.

According to Guo, Yang and Gao (2019) if the PP fibre was dispersed uniformly, the cracks in mortar encounter the PP fibre in expansion, and the presence of the fibre will force the cracks to change its development direction, or prevent the cracks from forming smaller micro-cracks, then the development trend of the mortar micro-cracks will be limited. Therefore, the dispersion method facilitated its distribution throughout the mixture, reducing the occurrence of micro-cracks in the mortar over time.

One of the functions of the fibre is to increase the resistance to retraction tensions. It was observed that the use in the tangled form (mixed according to the manufacturers' recommendation) caused the formation of clumps that resulted in greater dimensional variation than that observed for the reference sample (without fibre) not allowing them to spread throughout the surface of the samples.

Figure 9 - Shrinkage variation over time

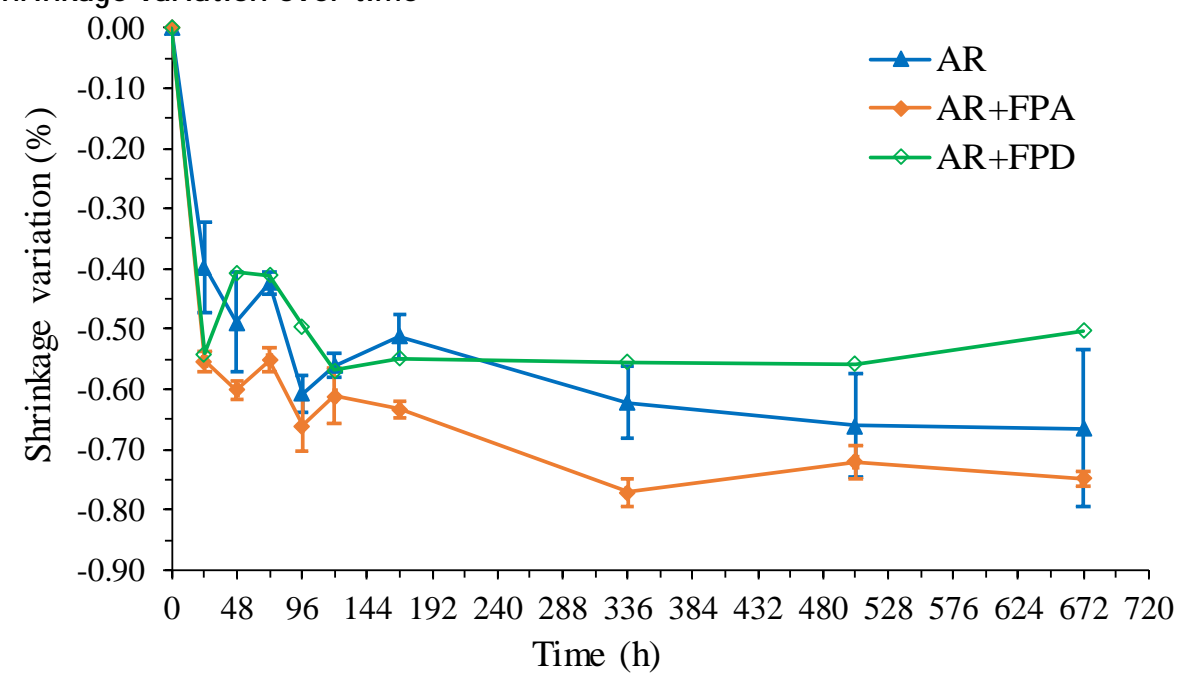

${ }^{5} \mathrm{NMAl}, \mathrm{C} . \mathrm{K}$. et al. Shrinkage-reducing admixtures. Concrete International, v. 20, n. 4, p. 31-37, 1998. 
Table 7 - Summary of statistical analysis of variance evaluating the impact of PPMF dispersion procedure in the tensile strength

\begin{tabular}{ccccc}
\hline Group & Count & Sum & Average & Variance \\
\hline AR & 5 & 9.09 & 1.82 & 0.078 \\
AR+FPA & 5 & 9.07 & 1.81 & 0.018 \\
AR+FPD & 5 & 7.82 & 1.56 & 0.016 \\
\hline
\end{tabular}

\begin{tabular}{c|cccccc}
\hline Source of variation & SQ & Gl & MQ & Fcalc & P-value & Fcritic \\
\hline Between groups & 0.21 & 2 & 0.11 & 2.86 & 0.10 & 3.89 \\
\hline In the groups & 0.44 & 12 & 0.04 & & & \\
\hline Total & 0.66 & 14 & & & & \\
\hline
\end{tabular}

Table 8 - Summary of statistical analysis of variance evaluating the impact of PPMF dispersion procedure in others

\begin{tabular}{c|c|c|c|c}
\hline Property & p-value & F & F-critic & Result \\
\hline Total Porosity & 0.08 & 3.18 & 3.89 & Statistically similar \\
Apparent porosity & 0.09 & 3.03 & 3.89 & Statistically similar \\
Tensile strength & 0.10 & 2.86 & 3.89 & Statistically similar \\
Modulus of elasticity & 0.12 & 2.49 & 3.89 & Statistically similar \\
Air-permeability & 0.49 & 0.75 & 3.89 & Statistically similar \\
Water absorption by capillarity - W & 0.34 & 1.19 & 3.89 & Statistically similar \\
\hline
\end{tabular}

\section{Statistical analysis}

To evaluate the impact of PPMF dispersion procedure, the ANOVA test was used. All parameters were evaluated statistically and presented the same results. Therefore, only one example of the ANOVA test was shown, as can be observed in the example of tensile strength in Table 7.

Table 8 presents a comparative summary of the values of F, Fcritic, and Proof Value (p-value) to all parameters evaluated.

\section{Conclusions}

The results obtained in this study showed:

(a) the dispersion procedure had no significant change in the spreading, indicating that all the mortars present similar consistency during application;

(b) in the hardened state, porosity, tensile strength, modulus of elasticity, air-permeability and water absorption by capillarity were statistically similar to the properties observed for the reference mortar and are not a function of the fibre dispersion methods;

(c) the use of dispersed fibres resulted in better control of the drying shrinkage, and is statistically different from the other compositions evaluated; and

(d) the effect of the polypropylene microfibre on dimensional variation control is potentially increased by dispersion procedure as it guarantees fibre homogeneity on rendering mortars.

\section{References}

AFROUGHSABET, V.; BIOLZI, L.; MONTEIRO, P. J. M. The effect of steel and polypropylene fibers on the chloride diffusivity and drying shrinkage of high-strength concrete. Composites Part B, v. 139, p. 8496, 2018.

ALTOUBAT, S. A.; LANGE, D. A. Creep, shrinkage and cracking of restrained concrete at early age. ACI Materials Journal, v. 98, p. 323-331, 2001.

ALY, T.; SANJAYAN, J. G.; COLLINS, F. Effect of polypropylene fibers on shrinkage and cracking of concretes. Materials and Structures, v. 41, p. 1741-1753, 2008. 
AMERICAN SOCIETY FOR TESTING AND MATERIALS. C114-15: standard test methods for chemical analysis of hydraulic cement. West Conshohocken, 2015.

AMERICAN SOCIETY FOR TESTING AND MATERIALS. C1365-06: standard test method for determination of the proportion of phases in Portland cement and portland-cement clinker using $\mathrm{x}$-ray powder diffraction analysis. Pennsylvania, 2011.

ASSOCIAÇÃO BRASILEIRA DE NORMAS TÉCNICAS. NBR 13276: argamassa para assentamento e revestimento de paredes e tetos: determinação do índice de consistência. Rio de Janeiro, 2016.

ASSOCIAÇÃO BRASILEIRA DE NORMAS TÉCNICAS. NBR 13278: argamassa para assentamento e revestimento de paredes e tetos: determinação da densidade de massa e do teor de ar incorporado. Rio de Janeiro 2005a.

ASSOCIAÇÃO BRASILEIRA DE NORMAS TÉCNICAS. NBR 13810: água: determinação de metais: método de espectrometria de absorção atômica por chama. Rio de Janeiro, 1997.

ASSOCIAÇÃO BRASILEIRA DE NORMAS TÉCNICAS. NBR 15259: argamassa para assentamento e revestimento de paredes e tetos: determinação da absorção de água por capilaridade e do coeficiente de capilaridade. Rio de Janeiro, 2005c.

ASSOCIAÇÃO BRASILEIRA DE NORMAS TÉCNICAS. NBR 15261: argamassa para assentamento e revestimento de paredes e tetos: determinação da variação dimensional (retração ou expansão linear). Rio de Janeiro, 2005b.

ASSOCIAÇÃO BRASILEIRA DE NORMAS TÉCNICAS. NBR 15630: argamassa para assentamento e revestimento de paredes e tetos: determinação do módulo de elasticidade dinâmico através da propagação de onda ultra-sônica. Rio de Janeiro, 2009.

ASSOCIAÇÃO BRASILEIRA DE NORMAS TÉCNICAS. NBR 15839: argamassa de assentamento e revestimento de paredes e tetos: caracterização reológica pelo método squeeze-flow. Rio de Janeiro, 2010.

ASSOCIAÇÃO BRASILEIRA DE NORMAS TÉCNICAS. NBR 7222: concreto e argamassa: determinação da resistência à tração por compressão diametral de corpos de prova cilíndricos. Rio de Janeiro 2011.

ASSOCIAÇÃO BRASILEIRA DE NORMAS TÉCNICAS. NBR NM 11-2: cimento Portland: análise química: determinação de óxidos principais por complexometria: parte 2: método ABNT. Rio de Janeiro, 2012b.

ASSOCIAÇÃO BRASILEIRA DE NORMAS TÉCNICAS. NBR NM 13: cimento Portland: análise química: determinação de óxido de cálcio livre pelo etilenoglicol. Rio de Janeiro, 2013.

ASSOCIAÇÃO BRASILEIRA DE NORMAS TÉCNICAS. NBR NM 16: cimento Portland: análise química: determinação de anidrido sulfúrico. Rio de Janeiro, 2012c.

ASSOCIAÇÃO BRASILEIRA DE NORMAS TÉCNICAS. NBR NM 18: cimento Portland: análise quimica: determinação de perda ao fogo. Rio de Janeiro, 2012a.

ASSOCIAÇÃO BRASILEIRA DE NORMAS TÉCNICAS. NBR NM 20: cimento Portland e suas matérias primas: análise química: determinação de dióxido de carbono por gasometria. Rio de Janeiro, 2012e.

ASSOCIAÇÃO BRASILEIRA DE NORMAS TÉCNICAS. NBR NM 22: cimento Portaland com adições de materiais pozolânicos: análise química: método de arbitragem. Rio de Janeiro, 2012d.

BANTHIA, N.; GUPTA, R. Influence of polypropylene fiber geometry on plastic shrinkage cracking in concrete. Cement and Concrete Research, v. 36, p. 1263-1267, 2006.

BOUZIADI, F.; BOULEKBACHE, B.; HAMRAT, M. The effects of fibers on the shrinkage of highstrength concrete under various curing temperatures. Construction and Building Materials, v. 114, p. 4048, 2016.

CARLSWÄRD, J. Shrinkage cracking of steel fiber reinforced self-compacting concrete overlays: test methods and theoretical modelling. Sweden, 2006. $261 \mathrm{f}$. Doctoral - Structural Engineering, Department of Civil and Environmental Engineering Division of Structural Engineering, Luleå University of Technology, Sweden, 2006.

EUROPEAN STANDARD. EN 197-1: cement: part 1: composition, specifications and conformity criteria for common cements. Brussels, 2000. 
GASPAR, P. L.; BRITO, J. Durabilidade, estados limite e vida útil de rebocos em fachadas. APFAC, 2010. Disponível em: https://www.apfac.pt/congresso2010/comunicacoes/Paper\%2091_2010.pdf. Acesso em: 20 jan. 2020.

GESOGLU, M. et al. Strain hardening ultra-high-performance fiber reinforced cementitious composites: effect of fiber type and concentration. Composites Part B, v. 103, p. 74-83, 2016.

GÜNEYISI, E.; GESOGLU, M.; ÖZBAY, E. Strength and drying shrinkage properties of self-compacting concretes incorporating multi-system blended mineral admixtures. Construction and Building Materials, v. 24, p. 1878-1887, 2010.

GUO, J.; YANG, Z.; GAO, G. Effect of Polypropylene fiber on properties of aeolian-sand mortar. Materials Science and Engineering, v. 472, p. 1-11, 2019.

INNOCENTINI, M. D. M. Permeability optimization and performance evaluation of hot aerosol filters made using foam incorporated alumina suspension. Journal Hazard Materials, v. 162, p, 212-221, 2009.

ISLAM, G. M. S.; DAS GUPTA, S. Evaluating plastic shrinkage and permeability of polypropylene fiber reinforced concrete. International journal of Sustainable Built Environment, v. 5, p. 345-354, 2016.

ITIM, A.; EZZIANE, K.; KADRI, E-H. Compressive strength and shrinkage of mortar containing various amounts of mineral additions. Construction and Building Materials, v. 25, p. 3603-3609, 2011.

KAKOOEI, S. et al. The effects of polypropylene fibers on the properties of reinforced concrete structures. Construction and Building Materials, v. 27, p. 73-77, 2012.

MA, Y.; TAN, M.; WU, K. Effect of different geometric polypropylene fibers on plastic shrinkage cracking of cement mortars. Materials and Structures, v. 35, p. 165-169, 2002.

MEHTA, P. K.; MONTEIRO, P. J. M. Concreto: estrutura, propriedades e materiais. São Paulo: Ibracon, 2008.

NILI, M.; AFROUGHSABET, V. The effects of silica fume and polypropylene fibers on the impact resistance and mechanical properties of concrete. Construction and Building Materials, v. 24, p. 927-933, 2010.

PELISSER, F. et al. Effect of the addition of synthetic fibers to concrete thin slabs on plastic shrinkage cracking. Construction and Building Materials, v. 24, p. 2171-2176, 2010.

QUARCIONI, V. A. et al. Aplicação de método de ensaio de permeabilidade ao ar em argamassas moldadas em laboratório. In: SIMPÓSIO BRASILEIRO DE TECNÓLOGIA DE ARGAMASSAS, 9., Belo Horizonte, 2011. Anais [...] Belo Horizonte: PCC, ANTAC, 2011.

QUARCIONI, V. A. et al. Estimativa da porosidade de argamassas de cimento e cal pelo método de cálculo de volumes. Ambiente Construído, v. 9, n. 4, p. 175-187, out./dez. 2009.

RAMEZANIANPOUR, A. A. et al. Laboratory study on the effect of polypropylene fiber on durability, and physical and mechanical characteristic of concrete for application in sleepers. Construction and Building Materials, v. 44, p. 411-418, 2013.

ROMANO, R. C. de O. Incorporação de ar em materiais cimentícios aplicados em construção civil. São Paulo, 2013. Tese (Doutorado em Engenharia de Construção Civil e Urbana) - Escola Politécnica, Universidade de São Paulo, São Paulo, 2013.

ROMANO, R. C. O.; TORRES, D. R.; PILEGGI, R. G. Impact of aggregate grading and air-entrainment on the properties of fresh and hardened mortars. Construction and Building Materials, v. 82, p. 219-226, 2015.

SAIZ-MARTÍNEZA, P. et al. Comparative study of the influence of three types of fibre in the shrinkage of recycled mortar. Materials Construction, v. 68, n. 332, e168, 2018.

SALVADOR G. A. B.Otimização da distribuição granulométrica do agregado miúdo para o uso em revestimentos de argamassa na cidade de sant' ana do livramento. Porto Alegre, 2005. $128 \mathrm{f}$. Trabalho de Conclusão (Mestrado em Engenharia) - Curos de Mestrado Profissionalizante em Engenharia, Escola de Engenharia, Universidade Federal do Rio Grande do Sul, Porto Alegre, 2005.

ŞANAL, I.; ÖZYURT, N.; HOSSEINI, A. Characterization of hardened state behavior of self-compacting fiber-reinforced cementitious composites (SC-FRCC's) with different beam sizes and fiber types.

Composites Part B, v. 105, p. 30-45, 2016. 
SELMO, S. M. S. Agregados miúdos para argamassas de revestimento. In: SIMPÓSIO NACIONAL DE AGREGADOS, 1., São Paulo, 1986. Anais. São Paulo, EPUSP, 1986.

SILVA, N. G. da et al. Efeitos do ar incorporado nas propriedades do estado endurecido em argamassas de cimento e areia. In: CONGRESSO BRASILEIRO DO CONCRETO, 51., Curitiba, 2009. Anais [...] Curitiba: Ibracon, 2009.

SILVA, N. G.; CAMPITELI, V. C. Correlação entre módulo de elasticidade dinâmico e resistências mecânicas de argamassas de cimento, cal e areia. Ambiente Construído, Porto Alegre, v. 8, n. 4, p. 21-35, 2008.

SUN, Z.; XUB, Q. Microscopic, physical and mechanical analysis of polypropylene fiber reinforced concrete. Materials Science and Engineering A, v. 527, p. 198-204, 2009.

VALCUENDE, M. et al. Influence of limestone filler and viscosity modifying admixture on the shrinkage of self-compacting concrete. Cement and Concrete Research, v. 42, p. 583-592, 2012.

YOUSEFIEH, N. et al. Influence of fibers on drying shrinkage in restrained concrete. Construction and Building Materials, v. 148, p. 833-845, 2017.

\section{Acknowledgements}

The authors wish to thank the Laboratory of Microstructure and Material Eco-efficiency - LME and the Institute of Technological Research (IPT) and its foundation (FIPT) for the financial and institutional support to carry out the experimental stage, through the New Talents Program No 01/2017. They would also like to thank the Coordenação de Aperfeiçoamento de Pessoal de Nível Superior - Brazil (CAPES) - Finance Code 001, and the Research Foundation of the State of São Paulo (FAPESP) [Grant Nº 2016/14473-6 (Kai Loh)] for their financial support, and Cristal Pigmentos do Brasil, Votorantim cimentos SA, Neo-Matex (fibras e têxteis técnicos para engenharia) and the Ibratin Industria e Comércio Ltda for their material support to this research work.

\section{Sérgio Roberto Andrade Dantas}

Departamento de Engenharia Civil | Universidade de São Paulo | Av. Professor Almeida Prado, trav. 2, 83 | São Paulo - SP - Brasil | CEP 05424-970 | Centro Tecnológico do Ambiente Construído | Instituto de Pesquisas Tecnológicas | Tel.: (11) 99884-3664 | E-mail: sergiodantas@usp.br

\section{Ramoel Serafini}

Departamento de Engenharia Civil | Universidade de São Paulo | Tel.: (54) 99925-0925 | E-mail: rserafini@usp.br

Roberto Cesar de Oliveira Romano

Departamento de Engenharia Civil | Universidade de São Paulo | Tel.: (11) 3091-5248 | E-mail: rcorjau@gmail.com

\section{Fúlvio Vittorino}

Centro Tecnológico do Ambiente Construído | Instituto de Pesquisas Tecnológicas | Av. Professor Almeida Prado, 532 | São Paulo - SP Brasil | CEP 05508-901 | Tel.: (11) 3767-4961 | E-mail: fulviov@ipt.br

Kai Loh

Departamento de Engenharia Civil | Universidade de São Paulo | Tel.: (11) 3091-5789 | E-mail: kai.loh@usp.br

\section{Ambiente Construído}

Revista da Associação Nacional de Tecnologia do Ambiente Construído

Av. Osvaldo Aranha, 99 - 3o andar, Centro

Porto Alegre - RS - Brasil

CEP 90035-190

Telefone: +55 (51) 3308-4084

Fax: +55 (51) 3308-4054

www. seer. ufrgs. br/ ambienteconstruido

E-mail: ambienteconstruido@ufrgs.br 